\title{
ANALISIS EKSOPOLISAKARIDA DARI BAKTERI ASAM LAKTAT HASIL FERMENTASI KEFIR KOLOSTRUM
}

\author{
Nurhasanah $^{1,2}$, Intan Tsamrotul Fu'adah ${ }^{2}$, Heri Satria', ${ }^{1,2}$, Suripto Dwi Yuwono ${ }^{1}$ \\ ${ }^{1}$ Jurusan Kimia, FMIPA, Universitas Lampung, Bandar Lampung, 35141 \\ ${ }^{2}$ Grup Riset Biokimia,, Jurusan Kimia, FMIPA, Universitas lampung, Bandar Lampung 35141 \\ nur.hasanah@fmipa.unila.ac.id
}

\begin{tabular}{|c|}
\hline $\begin{array}{l}\text { Artikel Info } \\
\text { Diterima } \\
\text { tanggal } \\
12.01 .2020\end{array}$ \\
\hline $\begin{array}{l}\text { Disetujui } \\
\text { publikasi } \\
\text { tanggal } \\
30.04 .2020\end{array}$ \\
\hline $\begin{array}{l}\text { Kata kunci : } \\
\text { asam laktat, } \\
\text { EPS, kefir, } \\
\text { kolostrum }\end{array}$ \\
\hline
\end{tabular}

\begin{abstract}
ABSTRAK
Eksopolisakarida (EPS) merupakan polisakarida yang disekresikan oleh mikroba keluar dinding sel, salah satunya oleh bakteri asam laktat (BAL). Kefir kolostrum merupakan minuman fermentasi yang berpotensi sebagai sumber BAL. Penelitian ini bertujuan untuk mendapatkan EPS dari BAL hasil kefir kolostrum. Untuk mencapai tujuan tersebut, isolat BAL hasil fermentasi kefir kolostrum diuji kemampuannya dalam menghasilkan EPS melalui pengamatan morfologi pada media MRSA dan karakter isolat ditentukan melalui identifikasi mikroskopik. Produksi EPS dilakukan dengan menumbuhkan kultur pada media MRSB dan dipisahkan dengan metode sentrifugasi. Analisis kandungan kadar total gula EPS diuji dengan metode fenol-sulfat. Hasil penelitian menunjukkan bahwa ada 13 isolat BAL penghasil EPS yaitu BEK 1-13 dengan 9 isolat berbentuk mucoid dan 4 isolat ropy. Produksi EPS tertinggi diperoleh dari isolat BEK 13 yaitu $4840 \mathrm{mg} / \mathrm{L}$, sedangkan kadar gula EPS tertinggi diperoleh dari isolat BEK 1 sebesar 579,56 $\mathrm{mg} / \mathrm{L}$.
\end{abstract}

\section{ABSTRACT}

Exopolysaccharide (EPS) is a polysaccharide secreted by microbes out of the cell wall, for instance is lactic acid bacteria (LAB). Colostrum kefir is a fermented beverage that has the potential as a source of $L A B$. This research aims to obtain EPS-LAB from colostrum kefir. The LAB isolates tested for their ability to produce EPS through morphological observations on MRSA media and the isolate character was determined through microscopic identification. EPS production is done by growing cultures on MRSB media and separated by centrifugation methods. Total EPS sugar content was tested by the phenol-sulfate method.. The result show that 13 isolates of LAB that produce EPS, namely BEK 1-13 which is 9 isolates mucoid and 4 isolates ropy. The highest EPS produced by BEK 13 isolate with $4840 \mathrm{mg} / \mathrm{L}$ and the highest sugar total of EPS produced by BEK 1 isolates which was $579.56 \mathrm{mg} / \mathrm{L}$.

\section{PENDAHULUAN}

doi: http://dx.doi.org/10.23960/aec.v5.i1.2020.p65-73

Anal.Environ.Chem.Anal. 
Eksopolisakarida (EPS) merupakan polimer polisakarida yang disekresikan keluar sel oleh mikroba. EPS yang dihasilkan mikroorganisme banyak digunakan pada industri, karena sifat fisiko-kimianya mirip dengan polisakarida dari tanaman (selulosa, pektin, pati) dan rumput laut (alginat dan karagenan). EPS berperan dalam rasa di mulut, tekstur, dan persepsi rasa dari produk fermentasi (Zubaidah, dkk., 2008). EPS juga digunakan sebagai bahan penghantar (carrier) senyawa aktif insulin oral pada industri farmasi dan sebagai pengental, penstabil, dan pengemulsi pangan (Dinoto, 2010).

Beberapa EPS yang diproduksi oleh BAL telah digunakan dalam bidang kesehatan dan produksi makanan (Malik, dkk., 2008). Karakteristik EPS adalah berbentuk seperti kapur berongga yang melekat dan sulit dikeluarkan. Jenis bakteri yang menghasilkan EPS secara luas digunakan untuk meningkatkan kualitas reologi yoghurt untuk menghambat sineresis, serta mampu mengganti starter yang lain yang biasanya digunakan dalam pengolahan yoghurt (Salminen, et al., 2004). Salah satu bakteri yang mampu menghasilkan EPS adalah Bakteri Asam Laktat (BAL). BAL yang menghasilkan lendir telah banyak digunakan dalam industri susu (Zubaidah dkk., 2008).

BAL digunakan dalam proses fermentasi susu sebagai upaya meningkatkan daya simpan yang lebih lama (Aristya, dkk., 2013). Salah satu produk fermentasi susu yakni kefir merupakan produk olahan susu menggunakan bibit kefir yang terdiri dari berbagai jenis probiotik dan khamir non pathogen (Safitri dan Swarastuti, 2011). Pada umumnya kefir dibuat dari susu sapi atau susu kambing, namun pada penelitian ini digunakan kolostrum sapi sebagai bahan bakunya. Hal ini dikarenakan, masih sedikit penelitian tentang kolostrum sapi ataupun kefir kolostrum.

Saat ini eksplorasi BAL penghasil EPS semakin meningkat karena kemampuan BAL mensintesis EPS dinilai penting bagi kesehatan. Beberapa BAL yang telah teridentifikasi menghasilkan EPS adalah Lactobacillus rhamnosus 9595M, Lactobacillus delbrueckii bulgaricus RR, Lactobacillus casei CG11, dan Lactobacillus Helventicus. Sedangkan kadar EPS terbesar yang berhasil diisolasi yakni 26\% yang berasal dari susu fermentasi jika dibandingkan dengan hasil EPS asal produk lain (Savadogo, et al., 2004).

Berdasarkan data-data penelitian yang telah disebutkan bahwa BAL dapat diisolasi dari berbagai produk berbasis susu, maka BAL pada fermentasi kefir memiliki kemungkinan yang

doi: http://dx.doi.org/10.23960/aec.v5.i1.2020.p65-73 Anal.Environ.Chem.Anal. 
cukup besar untuk ditemukan dan juga dapat menghasilkan EPS. EPS memiliki manfaat yang luas bagi kehidupan manusia terutama bidang industri, sehingga pada penelitian ini dilakukan isolasi EPS dari BAL hasil fermentasi kefir kolostrum.

\section{METODE}

\section{Alat dan Bahan}

Alat utama yang digunakan dalam penelitian ini adalah instrument analisis Spektrofotometer UV-Vis. Bahan yang digunakan adalah susu kolostrum, starter kefir, media deMan Rogosa and Sharpe Agar (MRSA), media deMan Rogosa and Sharpe Broth (MRSB), sodium chloride, akuades, susu skim, sukrosa, alkohol 96\%, glukosa, fenol 5\%, asam sulfat $96 \%$, alkohol 70\%, kristal violet, iodin, safranin, malachitegreen, dan $\mathrm{H}_{2} \mathrm{O}_{2} 3 \%$.

\section{Prosedur}

\section{Pembuatan Kefir Kolostrum}

Kolostrum sapi sebanyak $1 \mathrm{~L}$ dipasteurisasi pada suhu $70{ }^{\circ} \mathrm{C}$ selama 15 detik. Kemudian didinginkan pada suhu ruang (Usmiati, 2007 ) dan ditambahkan 5\% starter kefir. Susu kefir yang telah dibuat dimasukan ke dalam botol kaca dan difermentasi pada suhu ruang selama 48 jam. Kefir yang telah dibuat disimpan pada suhu $4{ }^{\circ} \mathrm{C}$ untuk menghambat laju pertumbuhan BAL (Otles, and Candigi, 2013)

\section{Seleksi BAL Penghasil EPS pada Media Padat}

Sampel kefir kolostrum diencerkan dengan menggunakan larutan $\mathrm{NaCl}$ fisiologis $0,85 \%$ steril dalam tabung reaksi secara bertingkat sampai $10^{-9}$. Kemudian dari masing-masing pengenceran diambil $100 \mu \mathrm{L}$ lalu ditanam ke dalam media MRSA dengan metode spread plate. Setelah itu diinkubasi dalam inkubator pada suhu $37^{\circ} \mathrm{C}$ selama 48 jam. Koloni BAL tunggal yang tumbuh, lalu ditumbuhkan kembali di permukaan medium MRSA yang diperkaya susu skim $90 \mathrm{~g} / \mathrm{L}$ dengan cara penotolan, kemudian diinkubasi selama 24 jam pada suhu $30^{\circ} \mathrm{C}$ (Sari, dkk., 2013). Isolat-isolat yang menunjukkan hasil positif menghasilkan EPS selanjutnya dikarakterisasi melalui identifikasi makroskopik dengan melihat bentuk sel dan jenis gram.

3. Isolasi EPS dari BAL pada Media Cair

doi: http://dx.doi.org/10.23960/aec.v5.i1.2020.p65-73

Anal.Environ.Chem.Anal. 
1 ose isolate diinokulasikan ke dalam $10 \mathrm{~mL}$ MRSB yang telah ditambahkan 5\% sukrosa dan diinkubasi selama 48 jam pada suhu $37^{\circ} \mathrm{C}$. Kemudian disentrifugasi pada suhu $4{ }^{\circ} \mathrm{C}$ dengan kecepatan 5000 rpm selama 30 menit, supernatannya diambil $5 \mathrm{~mL}$ dan ditambahkan etanol 96\% dingin sebanyak $10 \mathrm{~mL}$ (2x volume sampel) dan didiamkan selama semalam. Selanjutnya disentrifugasi pada suhu $4{ }^{\circ} \mathrm{C}$ dengan kecepatan $5000 \mathrm{rpm}$ selama 30 menit, lalu pellet dikeringkan dalam oven dengan suhu $100{ }^{\circ} \mathrm{C}$ selama 15 menit dan ditimbang berat kering EPS (Halim, dan Elok, 2013).

\section{Analisis Kandungan Gula Total EPS-BAL}

$1 \mathrm{~mL}$ EPS dimasukkan ke dalam tabung reaksi dan ditambahkan $1 \mathrm{~mL}$ larutan etanol 5\% lalu dikocok. Kemudian ditambahkan dengan cepat $5 \mathrm{~mL}$ asam sulfat $96 \%$, dibiarkan selama 10 menit, dikocok, dan ditempatkan dalam penangas air selama 15 menit pada suhu $100{ }^{\circ} \mathrm{C}$. Selanjutnya didinginkan dengan air mengalir dan diukur absorbansinya pada panjang gelombang $490 \mathrm{~nm}$ (Dubois, et al., 1956)

Pembuatan kurva standar larutan glukosa dilakukan dengan menggunakan Metode Dubois (Dubois et al., 1956) : $1 \mathrm{~mL}$ larutan glukosa standar yang mengandung 10, 20, 30, 40, 50, dan 60 ppm glukosa masing-masing dimasukkan ke dalam tabung reaksi dan ditambahkan larutan fenol 5\% sebanyak $1 \mathrm{~mL}$ lalu dikocok. Kemudian ditambahkan $5 \mathrm{~mL}$ asam sulfat $96 \%$ dengan cepat dan dibiarkan selama 10 menit. Larutan dikocok dan ditempatkan dalam penangas air selama 15 menit dengan suhu $100{ }^{\circ} \mathrm{C}$ dan diukur absorbansinya pada panjang gelombang 490 nm.

\section{HASIL DAN PEMBAHASAN}

\section{1. Bakteri Asam Laktat Penghasil EPS}

Bakteri Asam Laktat (BAL) merupakan bakteri yang mampu menghasilkan asam laktat, hidrogen peroksida, antimikroba dan hasil metabolism lain yang memberikan pengaruh positif bagi kesehatan. Pada penelitian ini telah dilakukan isolasi BAL dari kolostrum sapi yang difermentasi dengan starter kefir 5\% selama 48 jam pada suhu ruang $\left( \pm 27^{\circ} \mathrm{C}\right)$. Pada tahapan

doi: http://dx.doi.org/10.23960/aec.v5.i1.2020.p65-73 Anal.Environ.Chem.Anal. 
isolasi BAL dari kefir kolostrum didapatkan 13 isolat BAL yang disebut dengan isolate BEK (BAL EPS Kolostrum) $1-13$.

Tiga belas isolat BAL yang telah dimurnikan diseleksi untuk mengetahui potensinya dalam menghasilkan eksopolisakarida (EPS). Tahap ini dilakukan dengan pengujian pada media padat dan uji produksi EPS kasar pada media cair. Seleksi melalui media padat dilakukan untuk melihat morfologi masing-masing isolat BAL dalam menghasilkan EPS. Bakteri yang mampu menghasilkan EPS akan menunjukkan bentuk ropy (terdapat benang ketika ditarik dengan jarum ose) atau mucoid (berlendir). Berdasarkan data Tabel 1 terdapat 4 isolat berbentuk ropy dan 9 isolat mucoid. Tiga belas isolate tersebut selanjutnya diidentifikasi secara mikroskopik melalui pengecatan gram untuk mengetahui jenis gram dari isolate bakteri sekaligus melihat bentuk sel dari masing-masing isolat. Hasil dari tahapan seleksi isolat BAL dari kefir kolostrum dan keragaman antar isolate baik dari bentuk sel maupun jenis gramnya ditampilkan pada Tabel 1.

Tabel 1. Karakteristik Isolat BAL Penghasil EPS

\begin{tabular}{ccccc}
\hline No. & Isolat & $\begin{array}{c}\text { Morfologi } \\
\text { BAL-EPS }\end{array}$ & $\begin{array}{c}\text { Bentuk } \\
\text { Sel }\end{array}$ & Gram \\
\hline 1 & BEK 1 & mucoid & Basil & - \\
2 & BEK 2 & mucoid & Basil & - \\
3 & BEK 3 & mucoid & Basil & - \\
4 & BEK 4 & ropy & Basil & - \\
5 & BEK 5 & mucoid & Basil & - \\
6 & BEK 6 & ropy & Basil & - \\
7 & BEK 7 & mucoid & Basil & + \\
8 & BEK 8 & mucoid & Basil & - \\
9 & BEK 9 & ropy & Kokobasil & - \\
10 & BEK 10 & ropy & Kokobasil & - \\
11 & BEK 11 & mucoid & Kokobasil & - \\
12 & BEK 12 & mucoid & Basil & - \\
13 & BEK 13 & mucoid & Kokus & - \\
\hline
\end{tabular}

\section{Ekstrak EPS dan Kadar Gula Total EPS-BAL}

Isolat-isolat yang positif menghasilkan EPS selanjutnya diuji kemampuannya dalam memproduksi EPS dan ditentukan kadar glukosa yang dihasilkan. Penentuan kadar glukosa dari masing-masing isolat $(\mathrm{x})$ dilakukan dengan memplot nilai absorbansi sampel pada kurva standar

doi: http://dx.doi.org/10.23960/aec.v5.i1.2020.p65-73

Anal.Environ.Chem.Anal. 
glukosa yang memiliki persamaan $y=a x+b$; dimana $\mathrm{y}=$ absorbansi sampel, $\mathrm{a}=0,333$; $\mathrm{b}=$ 0,1188. Nilai absorbansi untuk masing-masing sampel disajikan pada Tabel 2 dan kurva standar glukosa dapat dilihat pada Gambar 1.

Tabel 2. Nilai absorbansi masing-masing isolat

\begin{tabular}{lc}
\hline Isolat & Absorbansi \\
\hline BEK 1 & 0,907 \\
BEK 2 & 0,511 \\
BEK 3 & 0,887 \\
BEK 4 & 0,534 \\
BEK 5 & 0,622 \\
BEK 6 & 0,647 \\
BEK 7 & 0,896 \\
BEK 8 & 0,783 \\
BEK 9 & 0,730 \\
BEK 10 & 0,525 \\
BEK 1 1 & 0,528 \\
BEK 12 & 0,598 \\
BEK 13 & 0,532 \\
\hline
\end{tabular}

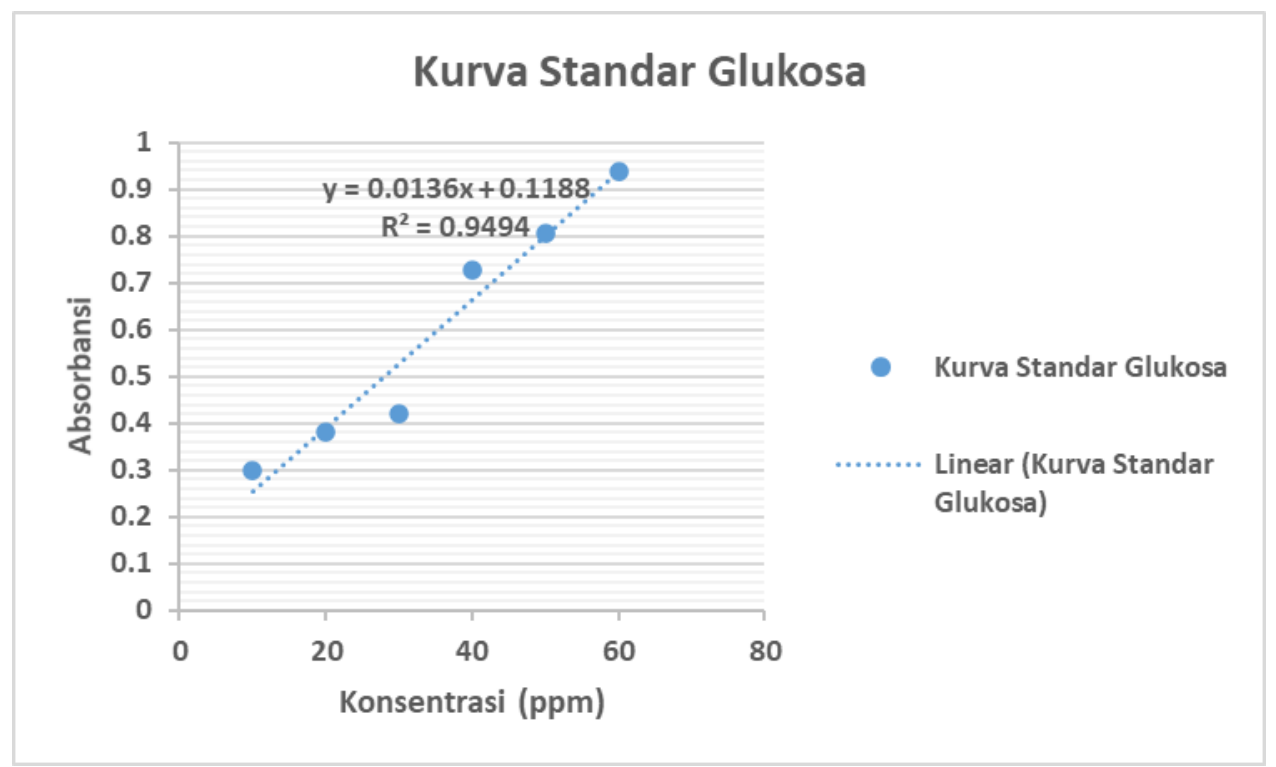

Gambar 1. Kurva standar glukosa

doi: http://dx.doi.org/10.23960/aec.v5.i1.2020.p65-73 Anal.Environ.Chem.Anal. 
Berdasarkan hasil pengukuran dan perhitungan diperoleh hasil berat kering EPS dan kadar gula untuk 13 isolat yang diperoleh ditampilkan pada Gambar 2.

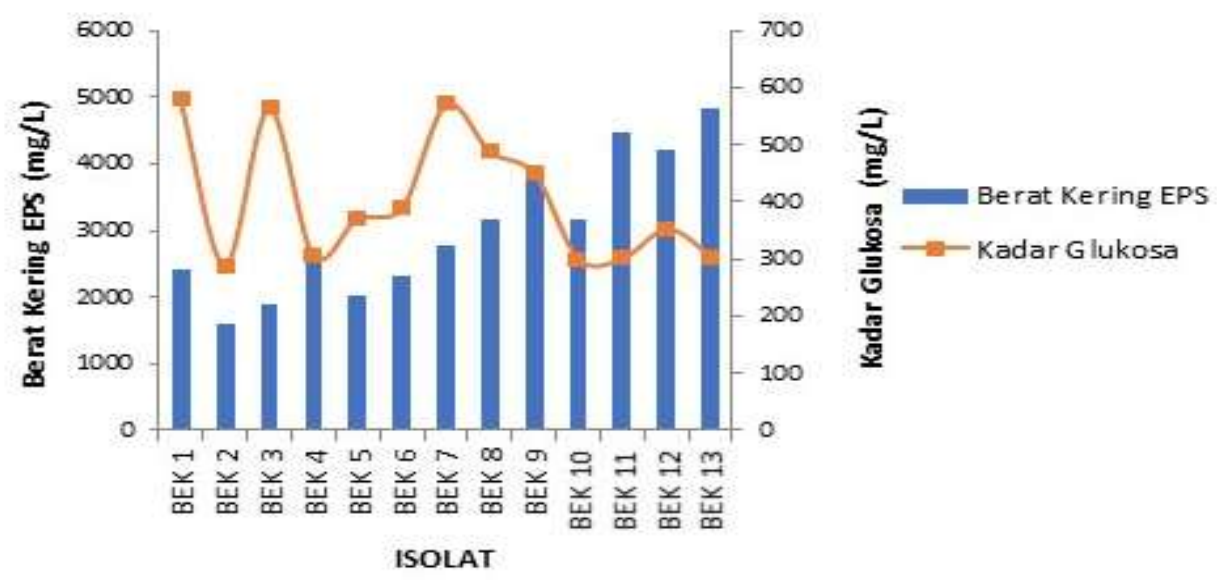

Gambar 2. Grafik Berat Kering dan Kadar Gula EPS

Berdasarkan Gambar 2, nilai EPS terendah dihasilkan oleh isolate BEK 2 yaitu $1600 \mathrm{mg} / \mathrm{L}$ sedangkan nilai EPS tertinggi dihasilkan oleh isolat BEK 13 yaitu 4840 mg/L. Nilai EPS dari BAL hasil fermentasi kefir kolostrum ini lebih tinggi jika dibandingkan isolat BAL komersial Lactobacillus casei dengan perlakuan yang sama yaitu sebesar 1340 mg/L (Halim, dan Elok, 2013). Hasil penelitian-penelitian sebelumnya yang mengisolasi EPS-BAL dari berbagai jenis produk, seperti dari susu kambing segar diperoleh kadar EPS 2600 mg/L (Widiyanti, 2014), fermentasi markisa diperoleh kadar EPS 2200 mg/L (Zahro, 2014), dan algerian raw camel milk dengan kadar EPS 740 mg/L (Mostefaoui et al., 2014), dibandingkan terhadap hasil berat kering EPS yang diperoleh dari penelitian ini cukup besar. Hal ini diduga karena perbedaan sumber sampel dan penambahan substrat untuk menghasilkan EPS yang diproduksinya.

Sedangkan hasil pengukuran kandungan gula total EPS yang dihasilkan masing-masing BAL lebih besar dibandingkan dengan kandungan gula yang dihasilkan oleh isolat BAL dari yoghurt yaitu L. delbrueckii B-3, L. bulgaris G12 dan Streptococcus thermophillus W22 yang masing-masing sebesar $255 \mathrm{mg} / \mathrm{L}, 224 \mathrm{mg} / \mathrm{L}$, dan $174 \mathrm{mg} / \mathrm{L}$ (Yuksekdag, and Salim, 2008), maupun BAL dari kefir yaitu L. Paracasei sebesar 238,23 mg/L (Xu, et al., 2010)

doi: http://dx.doi.org/10.23960/aec.v5.i1.2020.p65-73 Anal.Environ.Chem.Anal. 
Berat kering dan kandungan gula EPS yang diperoleh dari 13 isolat juga menunjukkan hasil yang beragam. Hal ini dimungkinkan adanya perbedaan strain antar isolat yang diakibatkan keragaman genetik di dalam kefir kolostrum terfermentasi yang merupakan tempat diisolasinya bakteri-bakteri ini. Berbedanya strain bakteri mengakibatkan jumlah metabolit yang dihasilkan pun tidak sama.

\section{KESIMPULAN}

Isolasi EPS dari BAL hasil fermentasi kefir kolostrum memiliki berat kering yang lebih besar dibandingkan dengan BAL komersial. EPS tertinggi dihasilkan dari isolat BEK 13 dengan berat kering sebesar $4840 \mathrm{mg} / \mathrm{L}$ dan kandungan gula tertinggi dihasilkan oleh isolat BEK 1 dengan kadar 579,56 mg/L.

\section{DAFTAR PUSTAKA}

Aristya, A.L., Legowo, A.M., dan Al-Baarri, A.N. 2013. Karakteristik Fisik, Kimia, dan Mikrobiologis Kefir Susu Kambing dengan Penambahan Jenis dan Konsentrasi Gula yang Berbeda. Jurnal Aplikasi Teknologi Pangan. 4(7): 39-47.

Dinoto, A. 2010. Produksi Eksopolisakarida Bakteri Usus Berbahan Baku Tepung Sagu (Metroxylon sp.) untuk Drug Delivery Sistem Berbentuk Nano Partikel dan Hidrogel. Laporan Kegiatan Tahap I Tahun Anggaran 2010. Kegiatan Program Insentif, Lembaga Ilmu Pengetahuan Indonesia-Ristek, Pusat Penelitian Biologi-LIPI. Cibinong, Bogor.

Dubois, M., Gilles, K.A., Hamilton, J.K., Rebers, P.A., and Smith, F. 1956. Colorimetric Method for Determination of Sugar and Related Substances. Analitical Chemistry. 28(3): 350-356.

Halim, C.N. dan Elok, Z. 2013. Studi Kemampuan Probiotik Isolat Bakteri Asam Laktat Penghasil Eksopolisakarida Tinggi Asal Sawi Asin (Brassica juncea). Jurnal Pangan dan Agroindustri. 1(2): 129-137.

Malik, A., Donna, M.A., Anandayu, N., dan Arry, Y. 2008. Skrining Gen Glukosiltransferase (GTF) dari Bakteri Asam Laktat Penghasil Eksopolisakarida. Makara Sains. 12(1): 1-6.

Mostefaoui, A., Ahcene H., Benalia Y., Saad B., and Abdelmalek B. 2014. Screening for Exopolysaccharide-Producing Strains of Thermophilic Lactic Acid Bacteria Isolated from Algerian Raw Camel Milk. African Journal of Microbiology Research. 8(22): 2208-2214.

doi: http://dx.doi.org/10.23960/aec.v5.i1.2020.p65-73

Anal.Environ.Chem.Anal. 
Otles, S. and Candigi, O. 2013. Kefir A Prebiotic Dairy Composition Nutritional Therepeutic Aspect. Pakistan Journal Of Nutrition. 2(2): 54-59.

Safitri, M. F. dan A. Swarastuti. 2011. Kualitas Kefir Berdasarkan Konsentrasi Kefir Grain. Indonesian Food Technologist Community. Semarang.

Salminen, S., Von, W.A., Morelli, L., Marteau, P., Brassart, D., De Vos, W.M., Fonden, R., Saxelin, M., Collins, K., Mogensen, G., Birkeland, S.E., and Mattila-Sandholm, T. 2004. A Review-Demonstration of Safety Probiotics. International Journal Food Microbology. 44(1-2): 93-106.

Sari, Y.N.M., Sumaryati, S., dan Jamsari. 2013. Isolasi, Karakterisasi, dan Identifikasi DNA Bakteri Asam Laktat (BAL) yang Berpotensi Sebagai Antimikroba dari Fermentasi Markisa Kuning (Passiflora edulis var. flavicarpa). Jurnal Kimia Universitas Andalas. 2(2): 115-130.

Savadogo, C.A.T., Ouattara, P.W.S., N. Barro, A.S. Ouattara, and A.S. Traore. 2004. Identification of Exopolysaccharides-Producing Lactic Acid Bacteria from Burkina Faso Fermented Milk Samples. African Journal Biotechnology. 3(3): 189-194.

Usmiati, S. 2007. Kefir Susu Fermentasi Dengan Rasa Menyegarkan. Warta Penelitian dan Pengembangan Pasca Panen Pertanian.

Widiyanti, K. 2014. Karakteristik Produksi Eksopolisakarida (EPS) dari Limbah Jerami Padi Oleh Isolat Bakteri Asam Laktat Lokal. (Skripsi). FMIPA Universitas Lampung. Bandar Lampung.

Xu, R., S. Ma, Y. Wang, Liu L., and Li P. 2010. Screening, Identification and Statistic Optimization of A Novel Exopolysaccharide Producing Lactobacillus paracasei HTC. African Journal of Microbial Research. 4(1): 783-795.

Yuksekdag, Z.N. and Salim, B. 2008. Influence of Different Carbon Sources on Exopolysaccharide Production By Lactobacillus delbrueckiisubspbulgaricus (B3, G12) and Streptococcus thermophilus (W22). Brazilian Archives of Biology and Technology. 51(1): 581-585.

Zahro, F. 2014. Isolasi dan Identifikasi Bakteri Asam Laktat Asal Fermentasi Markisa Ungu (Pasifloraedulis var. Sims) Sebagai Penghasil Eksopolisakarida. (Skripsi). UIN Malang. Malang.

Zubaidah, E., Yusnita, L., dan Ella, S. 2008. Produksi Eksopolisakarida oleh Lactobacillus plantarum B2 pada Produk Probiotik Berbasis Buah Murbei. Jurnal Teknologi Pertanian. 9(1): 59-68.

doi: http://dx.doi.org/10.23960/aec.v5.i1.2020.p65-73

Anal.Environ.Chem.Anal. 